\title{
Legal Issues in Implementing the Community Service Orders for Child Offenders in Malaysia
}

\author{
Norazla Abdul Wahab ${ }^{1}$, Mohd Al Adib Samuri ${ }^{1}$, Zuliza Mohd Kusrin ${ }^{1}$ \& Anita Abdul Rahim ${ }^{2}$ \\ ${ }^{1}$ Sharia Law Department, Islamic Studies Faculty, Universiti Kebangsaan Malaysia, Bangi, Malaysia \\ ${ }^{2}$ Faculty of Law, Universiti Kebangsaan Malaysia, Bangi, Malaysia \\ Correspondence: Mohd Al Adib Samuri, Sharia Law Department, Islamic Studies Faculty, Universiti Kebangsaan \\ Malaysia, Bangi 43600, Malaysia. Tel: 60-3-8291-5511.E-mail: al_adib@ukm.my
}

Received: September 4, 2013 Accepted: November 27, $2013 \quad$ Online Published: January 26, 2014

doi:10.5539/ass.v10n4p93

URL: http://dx.doi.org/10.5539/ass.v10n4p93

\begin{abstract}
Community service orders are a proposed alternative form of punishment for children who have been or are in conflict with the law. Despite an absence of clear laws in Malaysia pertaining to this order regarding its application to child offenders, it is nonetheless viewed as a more suitable form of punishment in protecting a child offender's best interest compared to a fine or a sentence of imprisonment. In light of the above, the objective of this article is to analyse two main legal issues relating to the future implementation of community service orders as an alternative form of sentence, such as the number of credit hours per sentence and the types of community service activities to be implemented. The research has shown that there is no uniformity in determining the minimum and maximum amount of credit hours in implementing community service orders against child offenders where some countries may have the maximum of 80 to 150 hours and 8 to 10 hours for the minimum. The research also found that community service orders have greatly benefited both the society and child offenders; the child offenders will be integrated back to the society and might as well undergo their rehabilitation process. This research may be significant in preparing guidelines or a complete implementation model for community service orders applicable to child offenders in Malaysia, as well as a reference for the Officers in the Community Service Department and Magistrates in the Child Courts in Malaysia.
\end{abstract}

Keywords: community service orders, child offenders, offenders, implementation

\section{Introduction}

The criminal justice system for children had undergone considerable change after numerous parties were made aware that the old justice system was no longer effective in handling the criminal involvement amongst child offenders. Imprisoning child offenders is no longer an effective punishment for children (Maguire \& Brown, 1998), and it is a major concern that it may result in recidivism among them (Petersilia, 2001). Abdul Rahman (2002) stressed that the sentence to be given to a child offender must aim to rehabilitate, educate and socially integrate them.

Silberman (1986) argued that community service orders are an effective way to rehabilitate child offenders. These orders are seen to be more suited to child offenders in protecting their interests as children compared to a sentence of imprisonment (Maguire \& Brown, 1998). Through community service orders, the offenders' spare time will be filled with community service activities that restrict their movements, thus simultaneously preventing them from committing or repeating the criminal acts (Hurd \& Miller, 1981; Perrier \& Pink, 1985). In fact, it is believed that these orders can educate child offenders and enable them to reintegrate with society (Silberman, 1986; Maher \& Dufour, 1987).

In Malaysia, community service orders were introduced in 2007 and only applied to young offenders aged between 18 and 21 years old as stated in section 293(1) (e) of the Criminal Procedure Code (Act 593). Despite a proposal from the Ministry of Women, Family and Community Development made in July, 2011 to amend the Child Act 2001 (Act 611) by repealing imprisonment as a punishment for child offenders and replacing it instead with community service orders (Utusan Malaysia, 2011), there is still no clear legal provisions relating to community service orders for child offenders as of the time this article was being written. Section 91of Act 611, which empowers the court to sentence child offenders, is also silent on the matter. 
However, magistrates in the Child Courts may use any of the legal provisions in Act 611 to issue a community service order to a child offender. For example, section 96(2) of the Child Act 2001 prevents children aged between 14 and 18 years from facing a prison sentence by listing several alternative sentences such as probation, fines, approved schools, Henry Gurney Schools, or 'others', which may be interpreted as, or mean to include, community service orders.

Besides the above, section 93(1) (e) of the Child Act 2001 can also be applied by magistrates to issue community service orders to child offenders. This provision allows the magistrate to decide whatever additional conditions he sees fit for an order of good conduct, where he may include a community service order in his decision. It is hereby proposed that community service orders are expressly provided for in the Child Act, particularly in Section 91 and other related sections, so that no legal issues arise upon its implementation later.

Thus, this research will focus on two main issues regarding the implementation of community service orders if they are indeed put into practice by the responsible bodies; such issues will include the number of credit hours and the type of community activities to be carried out.

\section{Literature Review}

Recent development in the criminal justice system bear witness the community service orders being accepted as a non-custodial form of punishment towards the criminal offender (Perrier \& Pink, 1985). These orders do in fact benefit the offender greatly, as well as society and the correctional system itself (Maher, 1994). Previous studies have extensively discussed community service orders as a form of alternative punishment to imprisonment or fines (Perrier \& Pink, 1985). In countries such as the USA, New Zealand, England and Wales, community service orders are a form of sentence for child offenders in their country, whether as an individual order, additional order, alternative to imprisonment or as a combined sentence (with imprisonment) (Silberman, 1986; Samuri, 2012).

Despite there being no clear evidence to prove that community service orders can reduce the rate of offenders' criminal involvement (Pink \& Perrier, 1985), a sentence of imprisonment will only cause an offender to experience anti-socialism (Maher \& Dufour, 1987). All throughout the offender's imprisonment, he or she cannot interact in any way with society in a community setting. This is highly detrimental to the offender, where his or her psychological health may weaken and give way to depression, anxiety and suicidal tendencies (Ireland, 2005). Imprisonment is also not the best solution to 'mould' a child, and is in fact not ideally suited to a child's instincts (Maguire \& Brown, 1998). Aside from this, the nation will be faced with the very real problem of overcrowding in the prisons (Perrier \& Pink,1985) in addition to the mounting cost of maintaining the prisoners, which will inevitably have to be covered by taxpayer's money (Maher, 1994).

Contrarily, by issuing community service orders that are strongly believed to benefit the offender and the community (Bergman, 1975), the offender is never separated from society (Maher \& Dufour, 1987). In fact, they are involved together with other members of society for performing activities (Maher, 1994). This will encourage them to bear responsibility and feel more aware of the needs of society (Silberman, 1986; Bergman, 1975); in addition, the offender's personality may be improved substantially through the acquisition of several new skills (Bergman, 1975). There may even be a point where the offender can continue those activities together with members of society after the duration of the community service orders have been served (Bergman, 1975; Hurd \& Miller, 1981).

Previous studies show that community service orders were first introduced in the Magistrate's Court in England and Wales in 1972 through a provision in the Criminal Justice Act 1972 (Perrier \& Pink, 1985). Similar to England and Wales, the order was made a form of punishment for criminal offences in Spain via a provision in the Penal Code 1995 (Blay, 2008). In the 1980s the order was also introduced in New Zealand and Australia (Blay, 2008). Interestingly, according to Silberman (1986) and Harris \& Wing Lo (2002), community service orders were already in use as an alternative punishment for child offenders since 1970s in the US and since 1974 in Switzerland. Britain too underwent a drastic change in its criminal justice system when it made community service orders an alternative sentence for child offenders (Bergman, 1975). This gives a new dimension to the criminal justice system in many countries, which are seen to pay more attention to the aspect of reparation when it comes to child offenders by integrating them with society (Perrier \& Pink, 1985).

There are several pros and critisms of issuing community service orders to the child offenders as highlighted by some researchers. For example, studies of the Probation Division, Administrative Office of the United States Courts (1989) and Hurd \& Miller (1981) explained that familial ties will not be severed when undergoing a community service order. In fact, the relationship between the offender and members of the community is also maintained. This is supported by Maloney's research (2007), where it states that the use of community service 
orders as an alternative form of punishment is suitable in protecting the best interest of a child offender. A part from that, Samuri et al. (2012) argued that some studies had pointed otherwise whereby the community service orders are seem to be ineffective and too soft compared to the seriousness of the crimes committed by the child offenders.

Basically, the sentence for child offender is based on the theory of deterrent and rehabilitation (Samuri et al., 2012). Samuri et al. (2012) argued that by looking at the best interest of the child in all matters concerning them, the rehabilitation theory is the ideal one to the child offenders. However in some occasion, severe sentences such as imprisonment and fines are continuously be used by the judiciary particularly Magistrate in sentencing the child offenders. Thus, in line with the aim of the Act 611 to uphold the best interests of the children (Awal, 2002), an alternative sentence or order which is based on the theory of rehabilitation such as community service order is suggested to be imposed on the child offenders (Samuri, 2012).

However, in the context of Malaysia, there is still a lack of clear legal framework on the implementation of community service orders for child offenders. In his study, Samuri (2012) explained that community service orders may be applied based on the provisions in section 93(1) (e) of the Child Act 2001 and section 293 of the Criminal Procedure Code (Act 593). However, the use of section 293 Act 593 may be questionable because the order is expressly provided for young offenders aged between 18 and 21 years old (Samuri, 2012) and not to children aged 18 and below according to the definition given in section 2(1) of the Child Act 2001.

There are very few research papers written on the subject of community service orders amongst child offenders in Malaysia, what more regarding certain issues of implementation of community service orders such as the number of credit hours for the order, the types of community-based activities to be carried out, and the concealment of the child offenders' identities. In fact, most of the previous studies discuss the implementation of community service orders from a perspective involving adult offenders who have been convicted of minor offences or young offenders rather than child offenders.

For example, in studies by Brennan \& Mason (1983) and Leibrich, Galaway, \& Underhill (1986), it was found that the minimum and maximum credit hours for community service orders differ from one nation to another (US, Britain, Canada, and New Zealand). Furthermore, there is no specific day as to when the offender is to begin serving the sentence, or for how many months it will take for the sentence to be completed. Similarly, the number of hours per day that the offender is to serve is also unspecified. However, Umbreit (1981) calculated the formula that one day's detention in prison is equivalent to six hours community service.

In most countries, the activities that are usually undertaken by the offender are individualistic in nature and do not involve active interaction with the community (Brennan \& Mason, 1983; Leibrich, Galaway, \& Underhill, 1986). Such activities include collecting litter, road works, painting buildings and marking roads, restoring signboards, repairing sewing machines, sweeping, mopping floors and so on. In his study, Leibrich, Galaway, \& Underhill (1986) also gave examples of activities that directly involve the society such as social services in hospitals, public health centres and homes for children with special needs. However, there is little discussion on the issue of protecting the identities of child offenders in any of the previous studies.

On the same note, a study conducted by the Probation Division, Administrative Office of the United States Courts (1989) focused more on the practical aspects of the implementation of community service orders, the preparations that the offender needs to make, the implementation procedure, follow-up programs and the offender's evaluation. Whereas in his study, Samuri (2012) explained several other issues concerning the implementation of community service order such as the type of offences that may incur this order and observation by the responsible bodies, in addition to the theoretical aspects, legal framework and the direction in which community service orders are going in Malaysia. In the same research, Samuri (2012) also briefly discussed issues such as the number of credit hours for community service order, the nature of the community service activities and the effects of violating community service orders within the Malaysian context.

Thus, this research will analyse the above-mentioned legal issues in more detail and will refer to the implementation models of community service orders for child offenders applied by the US, New Zealand, Australia and other relevant countries.

\section{Discussion}

There are numerous legal issues regarding the implementation of community service orders for child offenders. However, under this subtopic, this article shall only analyse two primary issues such as the total number of credit hours required for the order and the types of community service activities to be carried out. 


\subsection{Credit Hours Required for Completion of Community Service Orders}

Based on the existing legal provisions, the courts are the party responsible for determining the specific duration for an offender to complete a community service order. Section 293(1) (e) (i) of the Criminal Procedure Code (Amendment) 2010 for example provides that the duration of community service orders for young offenders may be up to 240 credit hours. However, in most countries, there is no uniformity in the determination of the minimum and maximum number of credit hours required to complete these community service orders. More importantly, there are no specific guidelines to determine the number of hours, and even if there were, there is no indication as to why that particular number of hours applies to the offence concerned (Brennan \& Mason, 1983).

In studies by Brennan \& Mason (1983) and Grafl (2007), the numbers of credit hours determined for child offenders in McClean County, Illinois, USA and in Austria are between 30 and 100 or up to 120 credit hours, depending on the seriousness of the crime. The determination of the number of those credit hours was made based on three degrees of seriousness of the offence; for minor offences, the offender will serve a community service order between 8 and 40 hours, 40 to 60 credit hours for offences of medium seriousness, and 61 to 80 hours for serious or major offences (Brennan \& Mason, 1983). Also in the USA, offenders in Multnomah County, Oregon, will serve between 24 and 80 hours for first-time offenders, and 24 hours for child offenders convicted of illegal possession of alcohol (Brennan \& Mason, 1983).

On the other hand, in Canada, the most recent number of credit hours issued to an offender in carrying out a community service order is from 30 to 150 hours compared to the previous total of hours between 10 and 400 credit hours (Brennan \& Mason, 1983). Whereas in Britain and Western Australia, 40 to 240 credit hours may apply to adult offenders, where 40 to 120 hours are issued for offences not punishable by imprisonment (Harris \& Lo, 2002) and 121 to 240 credit hours for offences punishable by imprisonment (Brennan \& Mason, 1983). In New Zealand and Spain, the offenders carry out their respective community service orders between 8 and 200 or 248 hours (Leibrich, Galaway, \& Underhill, 1986; Blay, 2008). Whereas in Ireland, the community service orders are carried out within 40 to 240 hour period, and must be completed within 12 months, or six months for orders of 120 credit hours. (Harris \& Lo, 2002).

By looking at the implementation of community service orders as practiced in the abovementioned countries, it may be concluded that the total number of credit hours required for a community service orders generally do not exceed 240 hours, which in line with the existing legal provisions in Malaysia for young offenders. In their study, Hurd \& Miller (1981) refute long durations up to 420 hours as is practiced in the US. Instead, they stressed that the ideal duration is 80 to 120 hours for implementation of community service orders, depending on the type of activity carried out every week. This also takes into consideration the readiness of the agencies involved, who may feel burdened when they are forced to bear the administrative costs for offenders with sentences exceeding 120 hours (Hurd \& Miller, 1981).

On a similar note, Leibrich, Galaway, \& Underhill (1986) mentioned that judges generally consider orders for durations from 8 to 200 hours as extreme and overboard. However, minimal credit hours, for example a total numbering below eight hours, is considered to be redundant and a waste of time (Leibrich, Galaway, \& Underhill, 1986). The primary concern regarding the implementation of low credit hours is that it would be incapable of rehabilitating the offender, plus it would also be inconsistent with the time and energy spent by the parties involved (Brennan \& Mason, 1983).

The question thus arises, how many credit hours would be ideal to be given to child offenders who have been sentenced with community service orders? Logically, for child offenders, the number of credit hours required for completion of a community service orders should be lower than what has been required for adult or young offenders. Thus, this research may agree with Brennan \& Mason (1983), Hurd \& Miller (1981) and Grafl (2007), whereby the maximum number of credit hours for child offenders should only be between 100 and 120 hours. In proposing the same in Malaysia, the maximum number of credit hours that will be given to the child offenders is 120 hours which is about half of the credit hours that is currently imposed upon young offenders.

However, for the children who have committed the serious or major offences, this research opined that the court may consider sentencing them to community service orders despite of being imprisonment, fines or any institutional detention but for a longer duration. For instance, they need to undergo the community service order for 240 hours which is the same maximum number of credit hours required for young adults, or 61 to 80 hours (Brennan \& Mason, 1983) or alternatively according to the proposed maximum numbers of credit hours to be implemented for child offenders in Malaysia which is 120 hours. This coincides with Thomas (2001), who opined that sentences such as imprisonment and fines are unreasonable for child offenders, even as punishment resulting from the offender's failure to complete the orders. 
In taking into consideration the findings of previous studies, the minimum number of credit hours required must be more than eight hours, which is between nine and ten hours, or if calculated in days, about one and a half day according to Umbreit's (1981) formula, whereby a day's detention in prison is equivalent to six hours community service. Based on that formula, an example of the calculation of credit hours for a community service order can be made as thus; a minor offence punishable by seven days imprisonment is multiplied by six hours, which brings the total number of credit hours to 42 for adult offenders. Whereas for child offenders, the number of credit hours for the same offence will be halved, making the total 21 credit hours of community service.

On the other hand, Harris \& Wing Lo (2002) suggest a 'one for one' formula, where imprisonment for a day is equivalent to a days' community service. For example, if the offender is sentenced to seven days imprisonment, then the community service order should also be implemented for seven days. This research however is in favour of formula given by Umbreit's (1981) and thus would proposed at least nine hours or one day and a half as the minimum credit hours for the child offenders to undergo the community service orders. This research further opined that the Umbreit's formula will be suit for the best interest of the child since the 'one to one' formula by Harris \& Wing Lo (2002) will cause a longer time for them to undergo the same.

Another notable absence from previous studies is a specific form of determination of the day that the offenders are supposed to commence with their community service orders sentences. These orders may be carried out according to the time specified by the participating bodies, such as weekday afternoons, or more commonly over the weekend, i.e. Saturday and Sunday (Leibrich, Galaway, \& Underhill, 1986). In other words, each offender has the right to determine their own spare time to allow them to carry out their community service orders sentence successfully (Leibrich, Galaway, \& Underhill, 1986).

If the order is carried out according to the offender's schedule, the officer in charge of monitoring the offender may face some difficulty in gathering other offenders who are also sentenced to community service, especially since community service activities are generally carried out in groups on specific days such as Saturday and Sunday. However, this matter can be easily handled if there is close cooperation from the institutions involved, where they can assist with the monitoring of the offenders; plus, the observing officers' willingness to work around the offenders schedules will ensure that the aim to rehabilitate the offenders and involve them in community activities can be smoothly and successfully achieved.

In New Zealand, the offender is required to report for duty as early as 8:00 a.m. on every Saturday for their community service orders (Leibrich, Galaway, \& Underhill, 1986). This differs from the situation in Australia, where community service orders are carried out for one week of every month (Israel \& Dawes, 2002). Whereas in the USA, community service orders are carried out over four, five or six days a week (Maloney, 2007). And in Victoria and Western Australia, the offenders will carry out their orders in community rehabilitation centres for 12 hours a week (Israel \& Dawes, 2002; Harris \& Lo, 2002).

Earlier studies have shown that there is no specific number of credit hours determined for a day's community service. The offenders will carry out their community service orders for six (Umbreit, 1981) or eight (Blay, 2008; Harris \& Lo, 2002) hours, but not for less than four hours a day (Blay, 2008). Usually, the community service commences in the morning, at around eight o' clock (Leibrich, Galaway, \& Underhill, 1986), and end after four, six or eight hours later.

In Malaysia, community service orders are proposed to be carried out by the child offenders at every weekend, i.e. on Saturdays or/and Sundays, which is normally they do not generally have their school or school-based activities on that days. They may choose either Saturday or Sunday or both Saturday and Sunday at every week starting at 8.00 a.m or 9.00 a.m and last after 6 hours (since the formula of Umbreit is proposed to be applied) or in the other words at $2.00 \mathrm{p} . \mathrm{m}$ or $3.00 \mathrm{pm}$. These are much more preferebble and practical despite of letting them to decide when exactly they are going to carry out their community service orders based on their free time or weekday afternoons or any other practises by Victoria and Western Australia, Australia and USA as discussed earlier.

However, if there is a good reason or occurrence that prevents the offender from carrying out his community service orders on any given week such as a death in the family, an important meeting, official business, a religious ceremony or community celebration (Israel \& Dawes, 2002), the offender is allowed some flexibility to not carry out the activity, but he must inform the respective officer responsible for monitoring him of his absence. The community service orders will then be postponed to the following week without contradicting the deadline in which the order must be completed. In Ireland, for example, community service orders which are for 40 to 120 hours must be completed within six to 12 months (Harris \& Lo, 2002).

The same approach will be proposed in Malaysia whereby the 120 hours (the proposed maximum credit hours to 
be implemented in Malaysia) or 240 hours (for serious and major offences) of community service orders must be completed within five to six or 10 to 12 months. It will be based on the culculation of dividing 120 or 240 hours to 6 hours per day (according to Umbreit's formula) which is equivalent to 20 or 40 days to be completed. If the child offenders have undergoing the said community service orders on Saturday or Sunday only in every month, they will be completing their community service orders within five to 10 months. Similarly if they are undergoing the same both on Saturday and Sunday in every month without fail, they will be finishing their community service orders within two and half months which is within the dateline imposed in Ireland i.e. six to 12 months.

\subsection{Types of Community Activities}

Based on the definition of community service, which among others include 'time allocated for work within a community' (Umbreit, 1981), this order should ideally have the offender be involved in activities that have direct interaction with society. This is in line with the main objective of community service, which is to encourage the offender to socialise and get to know issues concerning the community (Maher \& Dufour, 1987). The offender also undergoes a 'humanisation' process through these orders, whereby he makes an effort to increase his confidence and improve his personality (Maher, 1994), enhance his intellect, regain the community's trust in him and deliver the message to society that he and other offenders are only human and are not exempted from making mistakes (Maher, 1994).

Among the activities that are usually carried out in implementing community service orders include trash-collecting, roadworks, painting buildings and road lines, signboard restoration, repairing sewing machines, sweeping and mopping, grass-cutting and working with children in daycare (Brennan \& Mason, 1983), area and landscape maintenance, building restoration small repairs, housekeeping, serving meals, tenant management, gardening, cleaning up parks and maintenance work (Leibrich, Galaway, \& Underhill, 1986).

These activities are more individualistic and do not involve active physical interaction with society. However, the contribution and benefit of these activities to society cannot be denied. For example, dirty public restrooms and roads in need of mending may be in working and usable condition for the enjoyment of community individuals after being cleaned and repaired by offenders serving out their community service orders.

In most countries, Malaysia included, such activities are often carried out as implementation of community service orders. One way to look at it is that such activities may help to conceal the identities of child offenders from public knowledge as there is a lack of physical interaction with society. However, these same activities may not seem to fit the concept of community service, which requires communication and active offender-community relations where the activities carried out should greatly benefit the offender and other surrounding (Redman, 2010; Harris \& Lo, 2002).

This concurs with Silberman (1986) in that true community service should be able to improve the relationship between society and the offender, and not distance them. Building good ties between the offender and other members of the community may give a sense of self-belonging to the offender in his society (Silberman, 1986). Therefore, it would be more ideal if the offender could carry out his community service orders within his own community and extend it to other communities (Silberman, 1986).

The question is: what type of activities would truly capture and realise the aspirations of the community service order itself? The choice of activity or module in community service orders is highly important to ensure that the orders achieves its goal of rehabilitating and integrating the offenders with their communities (Thomas, 2001). The activities in these orders must be capable of raising civic awareness in the offender (Hoffmann \& Jiangmin, 2002). Some activities that directly involve society are, among others, community service in homes for the elderly, orphanages, charity homes and special care homes, schools, mental institutions and places of worship, hospitals or public healthcare centres, homes for children with special needs, assisting with office duties, and recreational activities in centres for education and sports or local community centres (Leibrich, Galaway, \& Underhill, 1986).

In a US case study conducted by Hurd \& Miller (1981), a young offender aged 18 years old was found guilty of killing an eagle, and was sentenced to 80 hours of community service in a national park. The offender, who was monitored by an officer of the same national park, had undergone activities such as splitting logs, picking up litter and feeding the birds. Besides being involved in advocating issues relating to the environment, the offender had also written about the problems faced by American eagles for the attention of the relevant authorities. This activity was well-received by all the parties involved, particularly the offender himself, where by the end of the activity, the offender had learned many new things that brought benefit to both himself and the community (Hurd \& Miller, 1981). 
The activities in community service orders may be further extended to social services in rural areas, an accomplishment made real by the South Australian Department of Correctional Services at the Anangu Pitjantjatjara Lands, a rural area situated in northern Western Australia (Israel \& Dawes, 2002). In the Malaysian context, similar community service activities may be carried out by offenders in indigenous peoples' villages or other rural interior areas in the states of Sabah and Sarawak to instill awareness of other peoples' struggles and material deficiencies.

This research therefore proposes that the activities in community service orders must be further developed and be given a new breath of life. The primary focus of the child offenders in the community service activities is their direct involvement with the community as what the comunity service orders are aimed to. Such individualistic activities such as grass-cutting, cleaning public restrooms, trash-collecting and so on can not anymore stand alone and it needs to be combined together with the community services activities in its real means. A case study conducted by Hurd Miller (1981) earlier had shown that the combination of the two will be able to increase positive values in the child offenders themselves. Therefore, this research opined that the community services activities must carried at least 80 to 90 percent of the activities that directly involve with the society and only 20 to 10 percent for the individual activities.

In relation to the above, the different locations and institutions or agencies involved in these community service activities should therefore be expanded, and close cooperation between the parties implementing the order and the other concerned agencies or institutions must be created (Israel \& Dawes, 2002). In addition, the offender may also be directly assimilated into a community through the activities he has carried out (Israel \& Dawes, 2002). Furthermore, this research also agrees that offenders should carry out community service orders that bear relevance to the offence they have committed as exemplified in Hurd \& Miller (1981). However, this has only been implemented in selected cases. For example, in cases of vandalism of public amenities, the child offenders will carry out their community service orders in public places such as cleaning public restrooms, restoring signboards, and other such activities related to public amenities.

Community service orders activities should also be broadened to exceed that of the existing types of activities. Therefore, rehabilitative activities for offenders such as counselling, education on the dangers of drug abuse, family therapy, preparation for facing the outside world and self-development programs (Maloney, 2007; Harris \& Lo, 2002) should be included as compulsory community service order activities. In one case study in Austria, a child offender aged 16 years old was involved in a socio-economic project that ran concurrently with his community service orders. Throughout the duration of the order, he successfully graduated from high school and ultimately became a businessman (Grafl, 2007). This is an extremely important example that can be used to devise a thorough community service order that can help a child offender rise above his past mistakes and reconnect him back to society.

Thus, this research also proposed that in future the compulsory rehabilitative activities for child offenders such as counselling or self-development programs should be a part of the community service activities as to be carried out by the child offenders or in the other words it will be replacing the 10 to 20 percent that allocated for the indivual activities.

\section{Conclusion}

In conclusion, this research finds that community service orders are a form of alternative sentencing that is most suited and beneficial to child offenders. However, to ensure the successful implementation of this community service orders, legal issues such as the number of credit hours and the types of community service activties to be carried out must be given serious attention, especially by the bodies concerned such as the Officers at the Community Service Department, Magistrates in the Child Courts and the media in general.

\section{Acknowledgement}

This article is a product of research under Project GGPM-2012-036 (Geran Galakan Penyelidik Muda), Universiti Kebangsaan Malaysia and Project FRGS/1/2012/SSI10/UKM/02/4 (Fundamental Research Grant Scheme-FRGS) Universiti Kebangsaan Malaysia.

\section{References}

Abdul Rahman, F. N. (2002). Children Who Kill-Little Monsters? In S. Z. Jamaluddin, N. Talib, \& J. M. Yusof (Eds.), Siri Undang-undang Mimi Kamariah Akta Kanak-Kanak 2001. Kuala Lumpur: Penerbit UM.

Awal, N. A. M. (2002). Child Act 2001: How Far Does It Conform to the UNCRC. In S. Z. Jamaluddin, N. Talib, \& J. M. Yusof (Eds.), Siri Undang-undang Mimi Kamariah Akta Kanak-Kanak 2001. Kuala Lumpur: Penerbit UM. 
Bergman, H. S. (1975). Community Service in England: An Alternative to Custodial Sentence. Federal Probation, 39(1), 43-46. Retrieved from https://www.ncjrs.gov/pdffiles1/Digitization/26234NCJRS.pdf

Blay, E. (2008). Work for the Benefit of the Community as a Criminal Sanction in Spain. The Journal of Community and Criminal Justice, 55(3), 245-258.

Brennan, T. P., \& Mason, L. (1983). Community Service: A Developing Concept. Federal Probation, 46(2), 49-57. Retrieved from https://www.ncjrs.gov/pdffiles1/Digitization/90383NCJRS.pdf

Grafl, C. (2007). Community Service in Austria: Main Results of a Feasibility Study. The Journal of Community and Criminal Justice, Probation Journal, 54(3), 251-261. http://dx.doi.org/10.1177/0264550507080359

Harris, R. J., \& Lo, T. W. (2002). Community Service: Its Use in Criminal Justice. International Journal of $\begin{array}{lllll}\text { Offender Therapy and Comparative } & \text { Criminology, 46(2), }\end{array}$ http://dx.doi.org/10.1177/0306624X02464005

Hoffmann, J. P., \& Xu, L. M. (2002). School Activities, Community Service, and Delinquency. Crime \& Delinquency, 48(4), 568-591. http://dx.doi.org/10.1177/001112802237130

Hurd, J. L., \& Miller, K. D. (1981). Community Service: What, Why, and How. Federal Probation, 45(4), 39-41.

Ireland, J. L. (2005). Psychological Health and Bullying Behaviour among the Adolescent Prisoners: A Study of Young and Juvenile Offender. Journal of Adolescent Health, 36(3), 236-243. http://dx.doi.org/10.1016/j.jadohealth.2004.02.026

Israel, M., \& Dawes, J. (2002). 'Something From Nothing': Shifting Credibility in Community Correctional Programmes in Australia. Criminology and Criminal Justice, 2(1), 5-25. http://dx.doi.org/10.1177/17488958020020010101

Leibrich, J., Galaway, B., \& Underhill, Y. (1986). Community Service Sentencing in New Zealand: A Survey of Users. Federal Probation, 50(1), 55-64. Retrieved from https://www.ncjrs.gov/pdffiles1/Digitization/101782NCJRS.pdf

Maguire, M., \& Brown, S. (1998). Understanding Youth and Crime; Listening to Youth. Buckingham: Open University Press.

Maher, R. J. (1994). Community Service: A Good Idea That Works. Federal Probation, 58, 20-23.

Maher, R. J., \& Dufour, H. E. (1987). Experimenting with Community Service: A Punitive Alternative to Imprisonment. Federal Probation, 51(3), 22-27. Retrieved from https://www.ncjrs.gov/pdffiles1/Digitization/108634NCJRS.pdf

Maloney, D. (2007). Restorative Community Service: Earning Redemption, Gaining Skills, and Proving Worth. Justice Alerts, 15(4), 214-219. Retrieved from http://reclaimingjournal.com/sites/default/files/journal-article-pdfs/15_4_Maloney.pdf

Perrier, D. C., \& Pink, F. S. (1985). Community Service: All Things to All People. Federal Probation, 49(2), 32-38. Retrieved from https://www.ncjrs.gov/pdffiles1/Digitization/99878NCJRS.pdf

Petersilia, J. (2001). When Prisoners Return to Communities: Political, Economic, and Social Consequences. Federal Probation, 65(1), 3-8.

Probation Division, Administrative Office of the United States Courts. (1989). Implementing Community Service: The Referral Process. Federal Probation, 53, 3-9.

Redman, D. (2010). A Community Engagement Orientation among People with a History of Substance Misuse and Incarceration. Journal of Social Work, 12(3), 246-266. http://dx.doi.org/10.1177/1468017310381288

Samuri, M. A. A. (2012a). Community Service Order for Juvenile Offenders: Theoretical and Legal Frameworks. Research Journal of Applied Science, 7(2), 126-131.

Samuri, M. A. A. (2012b). Perintah Khidmat Masyarakat bagi Kanak-kanak yang Berkonflik dengan Undang-undang: Teori, Kerangka Perundangan dan Halatuju di Malaysia. Jurnal Undang-undang, 16, 5-18. Retrieved from http://www.ukm.my/juum/JUUM\%202012/Juum\%2016_2012_13122012.pdf

Samuri, M. A. A., Omar, K., Awal, A. F., \& Sham, F. (2012). Legal Issues in Sentencing Child Offenders in Malaysia. Advances in Natural and Applied Sciences, 6(7), 1093-1098. Retrieved from http://www.aensiweb.com/anas/2012/1093-1098.pdf 
Silberman, S. (1986). Community Service as an Alternative Sentence for Juveniles. New England Journal on Criminal and Civil Confinement, 12(1), 123-150.

Smith, D. (2001). Electronic Monitoring of Offenders: The Scottish Experience. Criminology and Criminal Justice, 1(2), 201-214. http://dx.doi.org/10.1177/1466802501001002004

Thomas, T. (2001). Supervising Child Sex Offenders in the Community-Some Observations on Law and Practice in England and Wales, the Republic of Ireland and Sweden. European Journal of Crime, Criminal Law \& Criminal Justice, 9(1), 69-90. http://dx.doi.org/10.1163/15718170120519318

Umbreit, M. S. (1981). Community Service Sentencing: Jail Alternative or Added Sanction? Federation Probation, 45(3), 3-14.

Utusan Malaysia. (2011, July 27). Pinda Akta Elak Kanak-kanak Dipenjara. Retrieved from http://www.utusan.com.my/utusan/info.asp?y=2011\&dt=0727\&pub=Utusan_Malaysia\&sec=Dalam_Negeri \&pg=dn_08.htm

\section{Copyrights}

Copyright for this article is retained by the author(s), with first publication rights granted to the journal.

This is an open-access article distributed under the terms and conditions of the Creative Commons Attribution license (http://creativecommons.org/licenses/by/3.0/). 